\title{
Paternal obesity: how bad is it for sperm quality and progeny health?
}

\author{
Georges Raad ${ }^{1,3}$, Mira Hazzouri ${ }^{2}$, Silvia Bottini ${ }^{3}$, Michele Trabucchi ${ }^{3}$, Joseph Azoury ${ }^{1}$ and Valérie Grandjean ${ }^{3 *}$
}

\begin{abstract}
There is substantial evidence that paternal obesity is associated not only with an increased incidence of infertility, but also with an increased risk of metabolic disturbance in adult offspring. Apparently, several mechanisms may contribute to the sperm quality alterations associated with paternal obesity, such as physiological/hormonal alterations, oxidative stress, and epigenetic alterations. Along these lines, modifications of hormonal profiles namely reduced androgen levels and elevated estrogen levels, were found associated with lower sperm concentration and seminal volume. Additionally, oxidative stress in testis may induce an increase of the percentage of sperm with DNA fragmentation. The latter, relate to other peculiarities such as alteration of the embryonic development, increased risk of miscarriage, and development of chronic morbidity in the offspring, including childhood cancers. Undoubtedly, epigenetic alterations (ie, DNA methylation, chromatin modifications, and small RNA deregulation) of sperm related to paternal obesity and their consequences on the progeny are poorly understood determinants of paternal obesity-induced transmission. In this review, we summarize and discuss the data available in the literature regarding the biological, physiological, and molecular consequences of paternal obesity on male fertility potential and ultimately progeny health.
\end{abstract}

Keywords: Obesity, Fertility, Inheritance, Epigenetics, Small RNAs

\section{Résumé}

De plus en plus de données tendent à montrer que l'obésité paternelle a non seulement des effets néfastes sur la santé métabolique et reproductive de l'individu mais également sur celle de sa descendance. Les mécanismes mis en jeu dans ce processus incluraient des altérations physiologiques et hormonales des fonctions reproductives de l'homme obèse ainsi que des altérations épigénétiques au niveau du génome spermatique. Les modifications hormonales associées à l'obésité et qui se caractérisent principalement par une réduction du taux d'androgènes et une augmentation du niveau d'estrogène induiraient une altération des paramètres spermatiques, une diminution de la concentration ou de la numération totale en spermatozoïde et du volume séminal. Le stress oxydatif dans le testicule induirait une augmentation de la fragmentation de I'ADN spermatique et pourrait rendre compte de l'augmentation des risques de fausses-couches, des problèmes de développement embryonnaire ainsi que de l'augmentation des risques de mortalité chez la descendance, problèmes fréquemment rencontrés lorsque le père est. obèse. Les modifications épigénétiques (altérations des profils de méthylation de l'ADN, de la structure de la chromatine ou/et des profils d'expression des ARN spermatiques) induites par l'obésité sont, quant à elles, loin d'être comprises, même si elles sont, surement, les vecteurs clés de la transmission épigénétique paternelle des maladies métaboliques. L'objet de cette revue est. de résumer puis de discuter les différentes études expérimentales et épidémiologiques publiés à ce jour sur les conséquences physiologiques et moléculaire de l'obésité paternelle sur la santé de l'individu et sur celle de sa descendance.

Mots clés: obésité, fertilité, hérédité, épigénétique, petits ARN, sperm

\footnotetext{
* Correspondence: grandjea@unice.fr

${ }^{3}$ Université Cote d'Azur, Inserm, C3M (team 10), Nice, France

Full list of author information is available at the end of the article
} 


\section{Background}

Spermatogenesis is a tightly regulated process allowing the production of highly specialized cells, the spermatozoa. In order to give rise to viable progeny, spermatozoa requires two pivotal properties: while the first one is to fertilize oocytes to produce a diploid cell, the zygote, the second one is to bring to the zygote half of its genetic and epigenetic components. Consequently, we can presume that factors that modify the entire physiology of an individual might have negative impact on the quality of its sperm, for example the case of obesity.

As we know body weight homeostasis (from the Greek

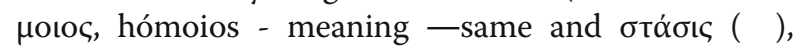
stásis - meaning —-standing) is crucial for protecting against weight fluctuations. Hence, this equilibrium is adjusted by the metabolic energy network and the control of food intake. However, an imbalance between the energy intake and energy expenditure leads to body weight fluctuations (e.g., gain or loss). The most common weight fluctuations are overweight and obesity, defined as an excessive accumulation of adipose tissue that is either generalized or localized within the body $[1,2]$. Two modalities can be used to assess corporal obesity: (i) the measurement of the waist circumference (measurement at the top of iliac crest according to National Health and Nutrition Examination Survey (NHANES) or (ii) the meansurement of the midpoint between the last palpable rib and top iliac crest according to the World Health Association (WHO)) and the calculation of the body mass index (weight/height ratio, BMI (body mass index $)=$ weight $(\mathrm{Kg}) /$ height $\left(\mathrm{m}^{2}\right)$ of an individual, allowing to approximately determine the percentage of fat in the body) [3]. Based on the latter ratio, individuals can be grouped into the following six categories: underweight, normal weight, overweight, obese class I, class II and class III (Table 1). Recent epidemiological studies have reported a striking increase prevalence of obesity worldwide. It is noteworthy to mention that these values reaches alarming percentages, for example 34.9\%, 36\% and $28.2 \%$ in USA, Saudi Arabia, and Lebanon respectively [4-7]. Strikingly, we pointed a high prevalence of $13 \%$ in young men of reproductive age suffering from overweight and obesity $[8,9]$. Besides other known

Table 1 Table showing the classification of the overweight and obesity [147].

\begin{tabular}{ll}
\hline Categories & Body mass index $\left(\mathrm{Kg} / \mathrm{m}^{2}\right)$ \\
\hline Underweight & $<18.5$ \\
Normal weight & $18.5-24.9$ \\
Overweight & $25.0-29.9$ \\
Class I obesity & $30.0-34.9$ \\
Class II obesity & $35.0-39.9$ \\
Class III, extreme obesity & $\geq 40$ \\
\hline
\end{tabular}

pathologies associated to obesity, such as hypertension, kidney disease, and type 2 diabetes, male infertility linked to obesity has sparkled the interest of the research community [10]. While several studies indicated that obesity could negatively impact sperm quality through physiological alterations (such as hormonal profiles modification (ie reduced androgen levels accompanied by elevated estrogen levels) $[11,12]$, and molecular alterations (such as epigenetic modifications which may have health cues in the offspring) [13-16], other studies did not support completely this association $[17,18]$. Accordingly, we elected to review and discuss the impact of paternal obesity on the male reproductive health as well as on the metabolic health of the progeny.

To write this review, we systematically collected papers published until September 2017, by searching Pubmed (URL:http://www.ncbi.nlm.nih.gov/pubmed/) and using keywords (such as epigenetic inheritance, sperm, obesity) related to the study background. This search was limited to English-languages publications.

\section{Paternal obesity and male reproductive health Effect of obesity on sexual function and seminal plasma composition}

Sedentary lifestyle and increase of calories intake by obese men could impair their reproductive health in different ways. On one hand, obese men are at higher risk of facing erectile dysfunction and reduced libido [19-21]. Interestingly, these functions were demonstrated to be restored after weight loss [22]. On the other hand, the sex accessory glands and the seminal plasma components could also be affected by male obesity [23]. The seminal plasma is an alkaline gelatinous fluid ( $\mathrm{pH} \sim 7.2$ ), made up of seminal vesicle secretions ( $\sim 60 \%$ of the total semen) and prostate gland secretions $(\sim 20 \%$ of the total semen volume). The secretions of the different sex glands contribute to the complex content of the seminal plasma [24]. This biological fluid could regulate sperm physiology by several ways such as: providing the energy source for spermatozoa [25], inducing biochemical modification of sperm during capacitation [26], and regulating acrosome reaction 4 [27]. Particularly, it was shown in mice that the excision of the seminal vesicle reduced the percentage of spermatozoa with progressive motility, accordingly this will drastically affect in the female uterine cavity, thus decreasing the pregnancy rate in this model [28].This study highlighted the importance of the seminal fluid as a transport and survival medium for spermatozoa. Furthermore, the seminal fluid can also modulate the female reproductive tract, and this finding was illustrated by several studies performed in mice, pigs, and humans [29]. For instance, it was shown that the excision of the seminal vesicle in a mouse model induced in part the up-regulation of some embryotrophic factor genes and the down-regulation of 
an apoptosis- inducing factor in the oviduct [30]. In addition, the absence of the seminal vesicle secretions impaired the blastocyst development and severely affected the resulting progeny that exhibited obesity, intolerance to glucose, and hypertension [30]. These results strongly indicated that the seminal fluid components regulate gene expression in the oviductwhich influences embryo development and progeny health. In addition, several studies in mammals highlighted the role of seminal plasma in regulating fetus growth trajectory [31-33]. Particularly, in a mouse model of diet-induced obesity, Binder and colleagues showed that seminal vesicle proteins and metabolites are affected by obesity [34]. Interestingly, clinical data reported that obese men are at higher risk of having a reduced semen volume and an alterated seminal plasma biochemistry compared to non-obese men [35]. Notably, the level of insulin, leptin, fructose, and interleukin 8 were found to be high in the semen of obese men. Conversely, adiponectin, progranulin, and alphaglucosidase levels were lower in obese men compared to lean men [36-39]. These alterations may affect the sperm biology by several ways. For instance, fructose is secreted by the seminal vesicle, and it is the major energy substrate in the semen. The level of seminal fructose was shown to be altered by several etiologies of male infertility [40,41]. Plus, a positive correlation was found between seminal fructose and sperm DNA fragmentation [42]. Thus, altered seminal fructose level in obese men probably reflects an altered seminal vesicle function [43]. Furthermore, the receptors of leptin and insulin were shown to be present on the sperm plasma membrane [44]. Probably, the alterations of the level of these two hormones in the seminal plasma of obese men may alter the endocrine signaling inside the spermatozoa. In parallel, it was demonstrated that the seminal plasma initiates changes in the cytokine profile of the uterine cavity and thus influence early embryo development and implantation [45]. For this reason, high levels of interleukin- 8 in the semen of obese men may alter the inflammatory response in the uterine cavity and may impair implantation and progeny health. Overall, these data opens new avenue to investigate the drawbacks of an altered seminal plasma composition in obese men on spermatozoa, the uterine environment, and embryo development.

\section{Effect of paternal obesity on testis}

Basically, the human testis is divided by a group of septa into 250 to 300 lobules. Each lobule is composed of interstitial tissue and 1-3 seminiferous tubules. While the interstitial and the tubular compartments are histologically distinguishable from each other, they are physiologically connected. All the processes involved in the production of male gametes (sperm cells) take place in the tubular compartment. However, the interstitial tissue is composed of Leydig cells $\left(200 \times 10^{6}\right.$ Leydig cells per testis), immune cells, blood vessels, fibroblasts, and connective tissue, and its main function is the production of male sex hormones. The integrity of both compartments is crucial for male gametes differentiation (Fig. 1) [46].

\section{Effect of obesity on Leydig cell physiology and androgen homeostasis}

Firstly described in 1850 by Franz Leydig, Leydig cells secrete the most important male steroid hormone called testosterone via steroidogenesis. These cells can easily access to the blood vessels, which permits the uptake of the luteinizing hormone (LH) and cholesterol from the circulation in order to produce testosterone. The produced male sexual hormone diffuses into the interstitial and tubular compartment to regulate spermatogenesis. In addition, when testosterone is released into the bloodstream it plays various roles in brain masculinization and sexual behavior, modulation of the larynx growth, stimulation of erythropoietin synthesis in the kidney, maturation of male sexual organs, hair growth, regulation of the bones muscle mass, and protein synthesis in the liver [47].

Furthermore, testosterone indirectly can regulate the action of the hypothalamus-pituitary-testis axis. In fact, male hypothalamus releases the gonadotropin-releasing hormone $(\mathrm{GnRH})$ that will bind to its receptor on the pituitary gonadotroph cells stimulating the expression and the release of LH and follicle-stimulating hormone (FSH) [46]. LH stimulates the testosterone production by the Leydig cells by binding to its receptor (LHR) on the Leydig plasma membrane [48]. The circulating testosterone is mainly bound to albumin or to sex hormone binding globulin (SHBG) which is originally synthesized in the liver. SHBG was demonstrated to reduce the clearance rate of androgens and regulates their access to target tissues [49]. In addition, the free circulating testosterone can be transformed in the adipose tissue into estrogen (E2) by an enzyme called aromatase (Fig. 2) [50]. Notably, in obese men, excess fat mass and hyperinsulinemia may alter SHBG production in the liver. Therefore, this will increase the amount of free testosterone available for conversion into E2 in the accumulated fat mass, which in turn will reduce GnRH secretion in the hypothalamus [51-53]. The above-mentioned pathophysiological changes could explain the increase in E2 concentration and the decrease in testosterone and gonadotropins in obese men [12,53]. It is known that, glucose and lipid homeostasis are essential for normal Leydig cells function. Thus, any alterations in glucose levels or consumption of high amounts of unhealthy fats can inhibit testosterone production and induce Leydig cells apoptosis [54-56]. 


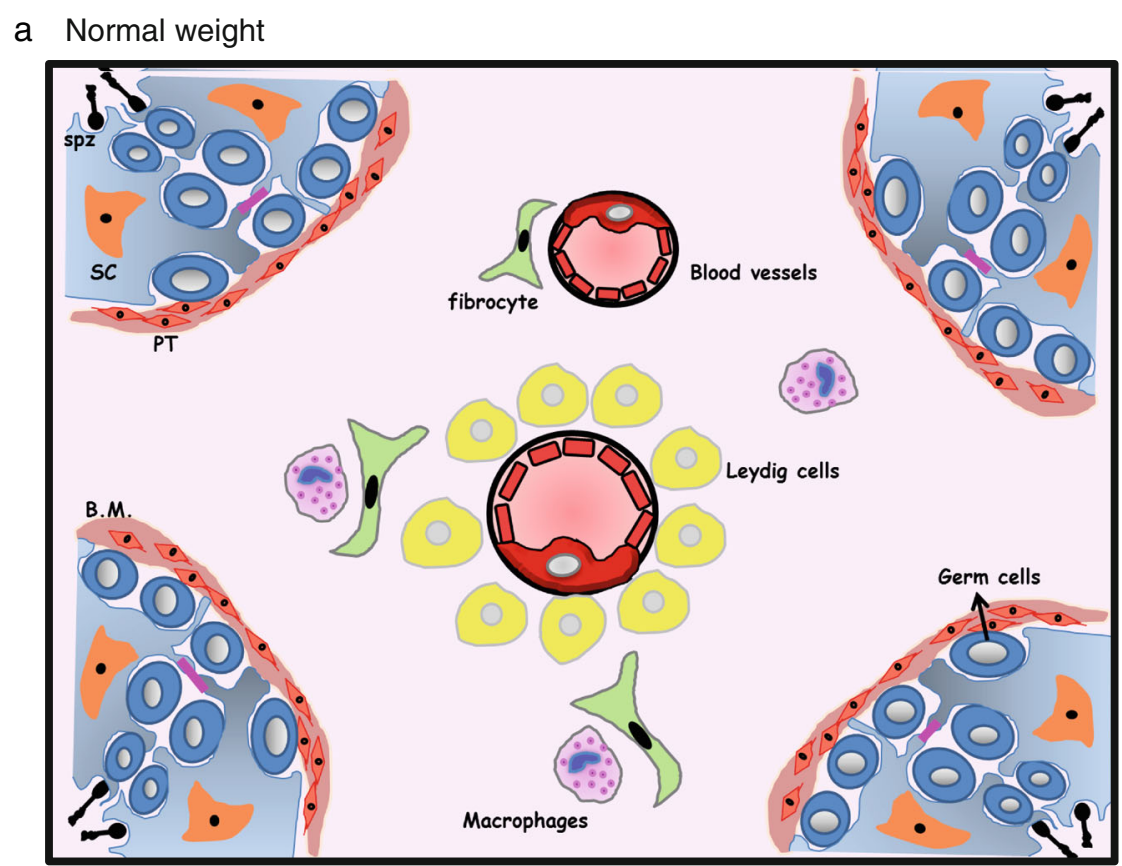

b Obese



Fig. 1 Illustration of testicular interstitial tissue in normal weight men (a) and obese men (b). Spz = Spermatozoa; sc = Sertoli cells; PT = peritubular cells; B.M. = basement membrane. TNF-alpha: Tumor necrosis factor alpha; MCP-1 = monocyte chemoattractant protein-1; F4/80: a defining marker of murine macrophage populations

\section{Effect of obesity on Sertoli cells functions}

Sertoli cells play a crucial role in germ cells development as well as in the regulation of spermatogenesis. These cells receive hormonal messages (FSH and testosterone) and local signals (autocrine and paracrine) to secrete molecules modulating their own function as well as that of germ cells and Leydig cells [47].

It was shown that the hormones involved in the regulation of spermatogenesis (FSH) and secreted by the Sertoli cells (inhibin B, AMH) were lower in obese men 


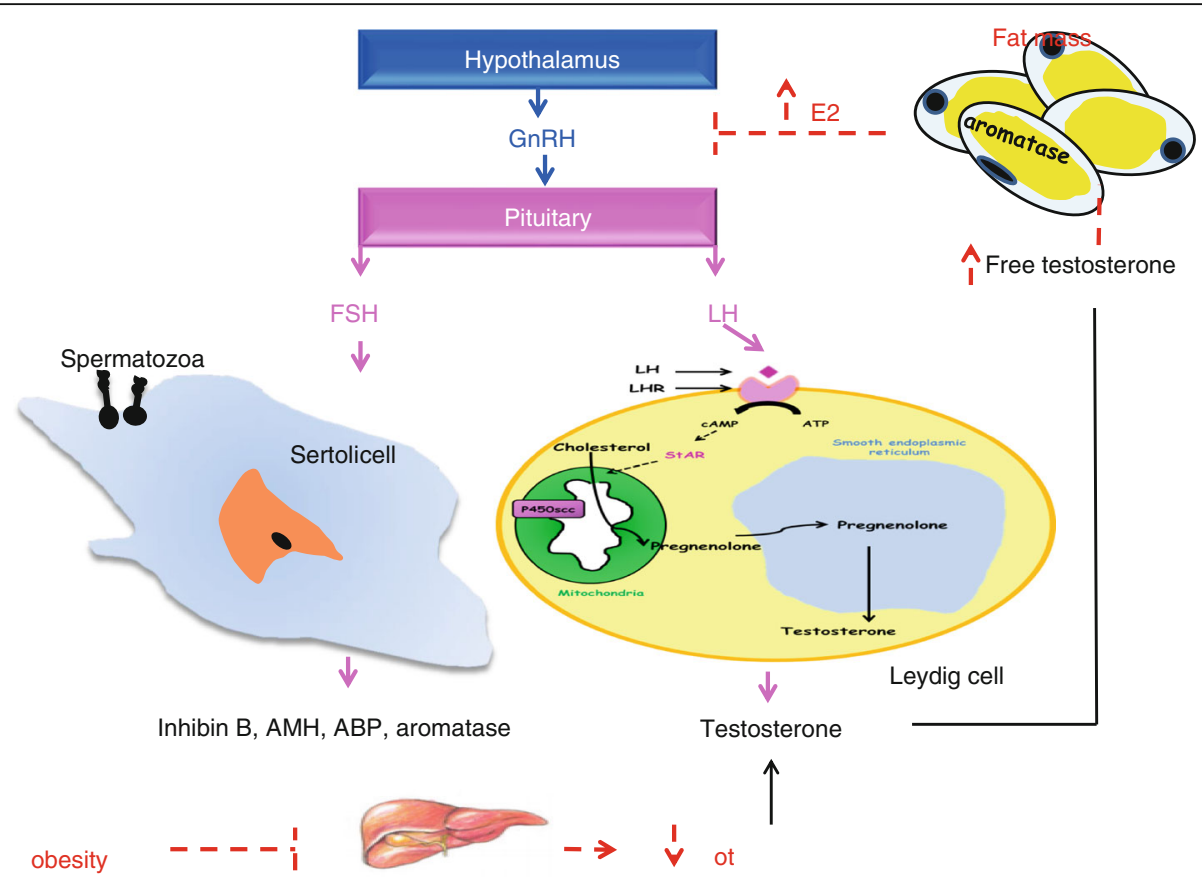

Fig. 2 Schematic representation of the hypothalamic pituitary testicular axis and hormone testicular production upon obesity. Solid lines represent the hormonal regulation in normal weight men; dashed lines represent the inhibitory effects of obesity. AMH: anti-müllerien hormone; ABP: androgen binding protein; E2: oestrogen; FSH: follicle stimulating hormone; GnRH: gonadotropin releasing hormone; LH: luteinizing hormone; LHR: luteinizing hormone receptor; SHBG: sex hormone binding globulin; StAR: steroidogenic acute regulatory protein

when compared to non-obese individuals [53, 57, 58]. Moreover, obesity may alter Sertoli cell metabolism which will affect germ cells. On the one hand, insulin stimulates several activities in Sertoli cells, mainly carbohydrate metabolism [59]. Lactate is produced by Sertoli cells under the control of insulin. It is the main energy source for germ cells, in addition ofhaving an antiapoptotic effect [60, 61]. Rato et al. showed that feeding rats with a high-energy diet increased the expression of glucose transporters and glycolytic enzymes in Sertoli cells. Altogether, these changes increased the level of lactate leading to oxidative stress in these cells [56]. In addition, testicular biopsies from diabetic men showed vacuolization of Sertoli cells. These observations may alter testicular glucose homeostasis (Fig. 1b) [62]. On the other hand, lipid metabolism also plays an important role in the testicular tissue function. Sertoli cells can uptake fats through various modes, either by passive diffusion through the plasma membrane or by protein facilitated transport, or from phagocytosed cells. Sertoli cells may utilize the internalized lipids to produce energy (ATP) or to generate polyunsaturated fatty acids (PUFAs). The PUFAs are essential for germ cells plasma membrane fluidity and flexibility and thus ultimately for fertilization [63]. The excessive consumption of saturated fats present in unhealthy diets may lead to their accumulation in testicular cells. This will affect the fatty acid composition of plasma membrane and the process of spermatogenesis [56, 64].
It is important to note that, the blood testis barrier (BTB) can modulate to a certain extent glucose and lipid uptake depending on their availability in blood [62]. However, histological analysis of testis from mice on high fat diet demonstrated that obesity can compromise the BTB integrity [65]. In the same perspective, obesity may bypass the BTB adaptive mechanisms to changing environmental conditions and thus targeting its main functions in selective transport and permeability [62].

\section{Effect of obesity on spermatogonia}

The spermatogonia are the final germline stem cells rising from primordial germ cells (PGC). They are characterized by a self-renewal capacity, and their commitment to spermatogenesis. Male obesity could also impair the survival and the differentiation of these cells [66]. Of particular interest, Interleukin 6 (IL-6) is a cytokine secreted by adipose tissue and macrophages. At elevated concentrations, it induces an inflammatory response. A recent study has shown that a high level of IL-6 is detected in the serum and testis of obese mice. We could speculate that this rise may decrease the level of a zinc finger protein (Zfp637) in spermatogonia. The downregulation of Zfp637 reduces spermatogonial differentiation [67]. Furthermore, obesity may induce testicular hyperthermia. It was found that specific spermatogonia (Adark) are more vulnerable to heat stress due to their high mitotic activity $[68,69]$. Altogether, 
these data highlight the negative impact of obesity on spermatogonial survival and differentiation.

\section{Impact of paternal obesity on sperm parameters and embryo development}

Paternal obesity negatively affects the sperm parameters

Many systematic reviews were performed in humans to evaluate the effects of male obesity on sperm parameters, DNA fragmentation, mitochondrial membrane potential, and fertility outcomes [11, 18, 70-72]. Although some discrepancies were noted [11, 18], overall these studies indicated that overweight and obesity in male are associated with high incidence of oligozoospermia and azoospermia [73-75], reduction in the percentage of normal sperm morphology $[11,18]$, increased percentage of sperm with DNA fragmentation and abnormal mitochondrial membrane potential $[11,75,76]$.

Some of these complications were found linked to testicular oxidative stress [77]. In fact, spermatogenesis is associated with a high rate of oxygen consumption and a resulting important ROS production by mitochondria causing oxidative stress [78]. The hyperglycaemia and hyperlipidemia would exacerbate this outcome. Indeed, intracellular accumulation of lipids increases $\beta$-oxidation rate of fatty acids. When overloaded, stressed testicular mitochondria reduce ATP production, and induce ROS overproduction [56]. More so, high-energy diets would reduce the testicular antioxidant system by reducing the expression of ROS-detoxifying enzymes in the testis such as proliferators-activated receptor $\gamma$ coactivator $1 \alpha($ PGC-1 $\alpha)$ and sirtuin 3 (SIRT3) [79]. Not surprisingly, studies in humans and rodents have demonstrated that obesity is associated with increased sperm ROS production [80, 81]. High ROS can produce important destructive effects in tissues by causing alterations in membranes causing an irreversible cellular damage. On the other hand, elevated ROS levels can induce DNA damage in spermatids [81] and in mature sperm [82-86]. Altogether, these findings reveal that obesity induces an oxidative stress in the testis and thus impairs sperm quality [56].

\section{Paternal obesity and embryo development}

It was demonstrated that obesity in rodents has a negative impact on pre-implantation embryo development, in particular we pointed a higher percentage of one -cell embryo block, delayed cell cycle progression, decreased blastocyst number, and altered carbohydrates metabolism $[87,88]$. Regarding human in vitro embryo development, very few reports were published. Whereas two studies didn't find any significant difference between obese and non-obese men regarding embryologic parameters, Bakos et al. spotted a significant decrease in blastulation rate with increasing BMI $[84,89,90]$. Strikingly, a recent meta-analysis included 115,158 participants, showed that paternal obesity may reduce the live birth rate per assisted reproductive technology (ART) cycle, and increases by $10 \%$ the risk of facing a non-viable pregnancy [11]. These findings highlighted the negative impact of obesity on the embryonic development.

\section{Paternal obesity and consequence on the metabolic health progeny}

A new area of research in andrology shed light on the long-term consequences of paternal health, at the time of conception, on the health of the offspring. For example, paternal age, smoking, and exposure to toxic chemicals may increase the risk of neuropsychiatric disorders, metabolic alterations, respiratory tract infection, and cancer in the offspring [91-97]. Similarly, accumulating epidemiological studies in humans suggest that paternal body mass index (BMI) may influence the health of the next generation [32, 98-102]. As reported by Kaati et al., when paternal grandfather experienced a surfeit of food at the age of 8-12 years old, the risk of grandson's death by T2DM increased by 4 folds. On the other hand, the risk of death by cardiovascular complications was reduced in case of low food availability during father's young age [100]. However, in research using human clinical samples the amount of material available is most often scarce as well as for ethical reasons, molecular mechanisms involved in this process are still largely unknown. Although human genetics and epigenetics epidemiological studies provided some clues on these mechanisms, however, the high degree of individual genetic/epigenetic variation render the interpretation of the data very complicated. Based on recent significant progress in rodent models $[15,103-113]$, we can now propose several mechanistic hypotheses. We will describe these molecular mechanisms in the next sections.

\section{Possible mechanisms of intergenerational and transgenerational inheritance of paternal acquired obesity Modifications known to be part of the epigenome, namely DNA methylation, chromatin structure, and non coding RNA might be involved in the molecular mech- anism of this process [114].}

\section{DNA methylation and epigenetic inheritance}

The chemical modification of DNA by the addition of a methyl group to the 5 position of cytosine was first discovered in 1948 by Rollin Hochkiss [115]. This modification is generally associated with long-term transcriptional repression [116]. Male and female gametes, like all cells, contain a specific DNA methylation landscape. Following fertilization, the majority of these modifications are erased to generate a totipotent zygote. This process is called epigenetic reprogramming [117]. However, some specific 
sequences escape this reprogramming process, and that is clearly the case of most of imprinted genes that contain differentially methylated regions regulating their parent of origin-specific expression [118]. This also appears to be the case for specific loci that have been marked following environmental changes such as unhealthy diet [34, 105, 107, 119]. In a cohort of 23 overweight/obese and 44 normal weight men human, Soubry et al. showed that sperm from overweight and obese men had significantly lower methylation rate at several imprinted genes [120]. The same authors previously found altered methylation profiles at several differentially imprinted regions in children born to obese parents [16]. Experiment studies support the association between obesity and DNA methylation alterations in gametes and in the somatic tissues of the progenies of the obese father. Along these lines, $\mathrm{Ng}$ Sheau-Fang et al. showed that male rats fed a high fat diet (HFD) gave birth to females (F1) intolerant to glucose with abnormal insulin secretion. These metabolic alterations were also associated with the histopathological changes in the pancreatic islets. At the molecular level, the key islet gene Il13ra2 (interleukin 13 receptor subunit alpha 2) was hypomethylated and its mRNA was found up-regulated in the pancreatic islets of the F1 offspring, suggesting a possible role of DNA methylation in the intergenerational inheritance of the paternal acquired phenotype [107]. In parallel, paternal diet-induced obesity in male mice model (C57BL6) was found to be associated with fetal growth restriction which is characterized by reduced fetal and placental weights. The fetal growth restriction is also correlated with an increased risk of developing obesity and diabetes in adulthood [121, 122]. The molecular analysis of the placentas showed that peroxisome proliferator-activated receptor alpha (Ppar $\alpha$ ) and caspase12 (Casp12) expression were significantly down-regulated in male placentas from obese fathers when compared to normal fathers, whereas the global DNA methylation was only increased in female placentas [23]. Furthermore, the paternal acquired obesity in mice alters the total body weight as well as glucose homeostasis in female offspring (F1) and to a lesser extent in males. These phenotypes were also transmitted to the second generation (F2) but in a sex-specific manner. At the epigenetic level, the elongated spermatids of the grandfather's testes fed a HFD were significantly hypomethylated when detected by immunohistochemistry on testis sections [105]. Finally, in a recent study, HFD was shown to alter DNA methylation signature of spermatozoa which was partially transmitted to the offspring [104].

While these studies showed that an altered DNA methylation signature of spermatozoa from HFD males could be passed through the progenies [104], a recent study indicated that sperm methylome is shaped by genetic and epigenetic variations but not by diet [123].

\section{Chromatin structure and epigenetic inheritance}

The majority of sperm DNA (negatively charged) is bound to small basic protamines (P1 and P2, positively charged proteins) causing DNA to coil into toroids [124]. The toroids are packaged into a highly condensed chromatin. Moreover, they are attached to the sperm nuclear matrix by their linker region DNA. The vast majority of the DNA is hidden within the toroids, for protection against nuclease digestion [125]. In addition, protamines cysteine residues can form disulfide bridges via the thiol $(-\mathrm{SH})$ groups, thus increasing the stability of the chromatin. At the functional level, this highly compacted structure represses transcription during spermiogenesis and protects the paternal genome during its journey in the female tract. Moreover, paternal protamines are replaced in the first 2-4 $\mathrm{h}$ after fertilization by maternal histones, rendering the chromatin more accessible to transcription machinery [126]. A recent meta-analysis showed that abnormal sperm protamination was associated with male infertility and sperm DNA damage. The normal ratio of P1-P2 is approximately 1 . This ratio could be affected by several internal or external factors such as thermal stress and cigarette smoking [127-130]. Not the majority of histones are replaced by protamines, but a small percentage from 5 to $10 \%$ of the human sperm genome retains paternal histones. In mature sperm of mice and humans, retained histones and their modifications (e.g., H3K4me3, H4K27me3) are not randomly distributed, and they are not replaced by maternal histones after fertilization [131, 132]. Interestingly, the retained nucleosomes were found in the promoters of different developmental genes (such as Hox-, Fox-, Sox-, gata family genes and noncoding RNAs (microRNAs and long non-coding RNAs)) [126, 133, 134]. Altogether, these findings highlight the possible role of nucleosome-bound sperm chromatin as a paternally inherited epigenetic regulator of diet induced obesity. Several studies supported this hypothesis. For example Terashima et al. have demonstrated that paternal acquired obesity can modulate histone composition at specific genes implicated in development and cell fate decision [135]. On the other hand, the histone deacetylases (HDAC) class III or Sirtuin (SIRT1-7) proteins are regulated by caloric intake. Of particular interest, SIRT6 is expressed in the mouse elongating spermatids and can play the role of ADP ribosyltransferase and $\mathrm{H} 3$ deacetylase (H3K9 and H3K56). Palmer et al. found that the protein level was significantly decreased in spermatids of HFD-fed male mice compared to controls. Consequently, the percentage of spermatids that stained positive to the H3K9ac antibody was higher in the HFD-fed mice compared to controls [81]. In parallel, low-protein diet was associated with a decrease in the H3K27me3 retention in sperm, specifically in Maoa (Monoamine 
oxidase) and Eftud1 (Elongation Factor Like GTPase 1) promoters [136].

Overall, these findings clearly show that sperm chromatin could be modulated by dietary conditions and could transfer epigenetic information to progeny.

\section{Sperm RNA and epigenetic modification}

As described above, sperm is a transcriptionally inactive cell which has long been thought to be devoid of RNA. However, several RNA populations including small noncoding RNAs such as microRNA (miRNAs), endogenous small interfering RNAs (endo-siRNAs), Piwi-interacting RNAs (piRNAs), were recently detected in sperm [137]. Since their discovery, several studies demonstrated their role in both early embryogenesis and epigenetic inheritance [138, 139]. For instance, using intra cytoplasmic sperm injection experiments, Lui et al. found that sperm partially deficient in sperm-borne miRNA and endosiRNA could successfully fertilize. However, embryos derived from these sperms displayed different embryonic alterations [139]. On the other hand, sperm-borne microRNA-34c was only detected in spermatozoa and zygotes but not in oocytes. It has been shown to be important for the one-cell embryo DNA synthesis and the first cleavage division [138]. Altogether, these data demonstrated the potential role of small RNA in embryonic growth.

Few years ago, we provided the first evidence that small non-coding RNA molecules (sncRNAs) act as trans-generational vectors of epigenetic information in mice. Indeed, we demonstrated that microinjection of specific microRNA into one cell embryo induced stable epigenetic modifications leading to specific and inherited phenotypes. Thus, cardiac hypertrophy, abnormal adult growth, and fur depigmentation can be induced by the microinjection into a mouse fertilized oocytes of miR-1, miR-124, and miR-221 respectively. Importantly, all these phenotypes can be maintained for at least 2 successive generations [140-142].

To further determine whether sperm RNAs would be critical determinants of the inheritance in an acquired disorder, micro-injection experiments were performed into one-cell embryos with sperm RNA from male mice exposed or not to environmental changes. Thus, sperm RNAs derived from male sperm exposed to postnatal trauma into the zygote, can faithfully reproduce the paternal phenotype in the offspring [143]. Similarly, we demonstrated that mice derived from the microinjection into naive embryos of sperm RNA from HFD-fed mice, even though they had been fed with a control diet, they developed in adulthood diet-induced pathologies such as obesity and signs of diabetes [15]. To identify RNA molecules involved in this epigenetic inheritance, small RNA deep-sequencing analysis of testis RNAs from HFD-fed mice and control was performed and revealed deregulation ofseveral classes of small-RNAs, such as miRNA, piRNA, and fragments of tRNAs. Notably, these results were consistent with previous studies [105]. Importantly, when microinjected into naive zygotes, one of the deregulated miRNA - the microRNA-19b, induced metabolic alterations that were similar to the diet-induced phenotypes [15]. In parallel, two other groups found that tRNA-derived small RNAs (tsRNA) might also contribute to intergenerational inheritance of metabolic disorders $[103,106]$. In contrast, synthetic microinjected-tsRNAs did not induce metabolic disorders in the offspring. The authors suggested that only post-transcriptionally modified tsRNAs could mediate thetransgenerational inheritance. This conclusion is supported by the evidence of elevated levels of $\mathrm{m}^{5} \mathrm{C}$ and $\mathrm{m}^{2} \mathrm{G}$ modifications in the tsRNAs of sperms from HFD-fed mice. In addition to the small RNA sperm population, a recent study indicates that long non-coding RNA could also acts as vectors of paternal epigenetic inheritance [108]. Hence, altogether these studies indicate that sperm small RNA is a pivotal paternal epigenetic vector involved in intergenerational inheritance of diet-induced metabolic disorders.

\section{Potential reversibility of the newly established epigenetic modifications}

The advantage of epigenetic alterations over genetic mutations is their potential reversibility [144]. Based on this property, a number of recent experimental studies aimed to demonstrate the reversibility of newly environmentalinduced epigenetic modifications. Thus, not only metabolic pathologies but also psychiatric disorders can be epigenetically inherited through the father, they appear to be partially prevented via diet/exercise/environmental intervention in fathers [112] [143, 145, 146]. However, these studies have been performed in rodent experimental models and there is a strong need to expand research on population-based data in order to enhance prevention strategies. To date, only Barrès' study has raised this issue [13]. In an obese and overweight human cohort, it was firstly demonstrated that environmental stress, such as obesity, might induce epigenetic changes in human spermatozoa. Notably, they, showed that sperm DNA methylation and RNA profiles are different between obese and lean men. More so, they noticed a significant deregulation of piRNA expression. Moreover, they showed in a specific cohort of obese men before and after surgery-induced weight loss a change in sperm methylome. This suggests the reversibility of newly sperm epigenetic diet-induced modifications.

\section{Conclusions}

There is a growing body of evidence supporting that obesity negatively affects sperm quality. Epigenome and 
small non-coding RNAs alterations in sperm of obese individuals were found to have a significant impact on male fertility potential and the health of the progeny. Owing to the reversibility of such alterations, obese patients are often encouraged to lose weight before being recommended a medical procedure. However, some doubts might be raised about the assumption that a balanced diet could totally or partially reverse epigenetic and small non-coding RNAs alterations.

\section{Abbreviations}

8-OHdG: 8-hydroxydeoxyguanosine; ABP: Androgen binding protein ADP: Adenosine monophosphate; AMH: Anti-müllerien hormone; ART: Assisted reproductive technology; ATP: Adenosine triphosphate; BMI: Body mass index; BTB: Blood Testis Barrier; Casp12: Caspase-12; E2: Oestrogen; Eftud1: Elongation Factor Like GTPase 1; FSH: Follicle stimulating hormone; GnRH: Gonadotropin releasing hormone; H3K4me3: Tri-methylation (me3) of lysine 4 (K4) on histone H3; H3K56: Lysine 56 of the histone 3; H3K9: Lysine 9 of the histone 3; H3K9ac: Acetylation of lysine 9 (K9) on histone H3; H4K27me3: Tri-methylation (me3) of lysine 27 (K27) on histone H3; HDAC: Histone deacetylases; HFD: High fat diet; II3ra2: Interleukin 13 receptor submit alpha 2; IL-6: Interleukin 6; LH: luteinizing hormone; $\mathrm{m}^{2} \mathrm{G}=\mathrm{N}^{2}$ : methylguanosine; $\mathrm{m}^{5} \mathrm{C}=5$-: methylcytosine; Maoa: Monoamine oxidase; MDA: Malondialdehyde; miRNA: microRNA; NHANES: National Health and Nutrition Examination Survey; NO: Nitric oxide; PGC-1a: Proliferators activated receptor $y$ coactivator 1a; PilK3r1: Phosphatidylinositol 3 kinase regulatory subunit; PiK3ca: Phosphatidylinositol 3 kinase catalytic subunit; piRNAs: Piwiinteracting RNAs; Ppar: Peroxisome proliferator-activated receptor alpham; PUFAs: Polyunsaturated fatty acids; RNA: Messenger ribonucleic acid; ROS: Reactive oxygen species; SGA: Small for gestational age; SHBG: Sex hormone binding globulin; SHBG: Sex hormone binding globulin; siRNAs: Small interfering RNAs; SIRT: Sirtuin protein; sncRNAs: Small non-coding RNA; T2DM: type 2 diabetes mellitus; tRNAs: Transfer ribonucleic acid; tsRNA: tRNA-derived small RNAs; WHO: World Health Association; Zfp: Zinc finger protein

\section{Acknowledgements}

Not applicable.

\section{Funding}

G.R. was supported by a fellowship from CNRS-L. This work was supported by grants of "Agence Nationale de la Recherche" (ANR-12-ADAPT-0022) to VG, Fond Français pour l'Alimentation et la Santé (12-A-52), France to VG; ANR through the "Investments for the Future" \# ANR-11-LABX-0028-01

(LABEX SIGNALIFE) to MT.

\section{Availability of data and materials}

Not applicable.

\section{Authors' contributions}

GR and VG wrote the manuscript. MH, MT, SB and JA have been involved in editing the manuscript critically. All authors read and approved the final manuscript.

\section{Ethics approval and consent to participate}

Not applicable.

\section{Competing interests}

The authors declare that they have no competing interests.

\section{Publisher's Note}

Springer Nature remains neutral with regard to jurisdictional claims in published maps and institutional affiliations.

\section{Author details}

'Azoury-IVF clinic, Mount Lebanon Hospital, 5th floor, Camille Chamoun bvd, Beirut, Lebanon. ${ }^{2}$ Faculty of Sciences 2, Lebanese University, Fanar, Lebanon. ${ }^{3}$ Université Cote d'Azur, Inserm, C3M (team 10), Nice, France.
Received: 3 July 2017 Accepted: 9 October 2017

Published online: 26 October 2017

\section{References}

1. Blundell JE, Cooling J. Routes to obesity: phenotypes, food choices and activity. Br J Nutr. 2000;83(Suppl 1):S33-8.

2. Proietto J, Baur LA. 10: management of obesity. Med J Aust. 2004:180:474-80.

3. Pettitt DJ, Talton JW, Liese AD, Liu LL, Crimmins N, West NA, et al. Comparison of two waist circumference measurement protocols: the SEARCH for diabetes in youth study. Pediatric obesity. 2012;7:e81-5.

4. Nasreddine L, Naja F, Chamieh MC, Adra N, Sibai AM, Hwalla N. Trends in overweight and obesity in Lebanon: evidence from two national crosssectional surveys (1997 and 2009). BMC Public Health. 2012;12:798.

5. Al-Quwaidhi AJ, Pearce MS, Critchley JA, Sobngwi E, O'Flaherty M. Trends and future projections of the prevalence of adult obesity in Saudi Arabia, 1992-2022. East Mediterr Health J. 2014;20:589-95.

6. Ogden CL, Carroll MD, Kit BK, Flegal KM. Prevalence of childhood and adult obesity in the United States, 2011-2012. JAMA. 2014;311:806-14.

7. van Vliet-Ostaptchouk JV, Nuotio ML, Slagter SN, Doiron D, Fischer K, Foco $L$, et al. The prevalence of metabolic syndrome and metabolically healthy obesity in Europe: a collaborative analysis of ten large cohort studies. BMC Endocr Disord. 2014;14:9.

8. Collaborators GMaCoD. Global, regional, and national age-sex specific allcause and cause-specific mortality for 240 causes of death, 1990-2013: a systematic analysis for the global burden of disease study 2013. Lancet. 2015:385:117-71.

9. Lobstein T, Jackson-Leach R, Moodie ML, Hall KD, Gortmaker SL, Swinburn $\mathrm{BA}$, et al. Child and adolescent obesity: part of a bigger picture. Lancet. 2015;385:2510-20.

10. Craig JR, Jenkins TG, Carrell DT, Hotaling JM. Obesity, male infertility, and the sperm epigenome. Fertil Steril. 2017;107:848-59.

11. Campbell JM, Lane M, Owens JA, Bakos HW. Paternal obesity negatively affects male fertility and assisted reproduction outcomes: a systematic review and meta-analysis. Reprod BioMed Online. 2015;31:593-604.

12. Pitteloud N, Hardin M, Dwyer AA, Valassi E, Yialamas M, Elahi D, et al. Increasing insulin resistance is associated with a decrease in Leydig cell testosterone secretion in men. J Clin Endocrinol Metab. 2005:90:2636-41.

13. Donkin I, Versteyhe S, Ingerslev LR, Qian K, Mechta M, Nordkap L, et al. Obesity and bariatric surgery drive epigenetic variation of spermatozoa in humans. Cell Metab. 2016;23:369-78.

14. Fullston $T$, Shehadeh $H$, Sandeman LY, Kang WX, LL W, Robker RL, et al. Female offspring sired by diet induced obese male mice display impaired blastocyst development with molecular alterations to their ovaries, oocytes and cumulus cells. J Assist Reprod Genet. 2015;32:725-35.

15. Grandjean V, Fourre S, De Abreu DA, Derieppe MA, Remy JJ, Rassoulzadegan M. RNA-mediated paternal heredity of diet-induced obesity and metabolic disorders. Sci Rep. 2015;5:18193.

16. Soubry A, Murphy SK, Wang F, Huang Z, Vidal AC, Fuemmeler BF, et al. Newborns of obese parents have altered DNA methylation patterns at imprinted genes. Int J Obes. 2015;39:650-7.

17. Bandel I, Bungum M, Richtoff J, Malm J, Axelsson J, Pedersen HS, et al. No association between body mass index and sperm DNA integrity. Hum Reprod. 2015;30:1704-13.

18. Macdonald AA, Stewart AW, Farquhar CM. Body mass index in relation to semen quality and reproductive hormones in New Zealand men: a crosssectional study in fertility clinics. Hum Reprod. 2013:28:3178-87.

19. Bacon CG, Mittleman MA, Kawachi I, Giovannucci E, Glasser DB, Rimm EBA Prospective study of risk factors for erectile dysfunction. J Urol. 2006;176: 217-21.

20. Larsen SH, Wagner G, Heitmann BL. Sexual function and obesity. Int J Obes. 2007:31:1189-98.

21. Traish AM, Feeley RJ, Guay A. Mechanisms of obesity and related pathologies: androgen deficiency and endothelial dysfunction may be the link between obesity and erectile dysfunction. FEBS. 2009;276:5755-67.

22. Esposito K, Giugliano F, Di Palo C, Giugliano G, Marfella R, D'Andrea F, et al. Effect of lifestyle changes on erectile dysfunction in obese men: a randomized controlled trial. JAMA. 2004:291:2978-84.

23. Binder NK, Beard SA, Kaitu'u-Lino TJ, Tong S, Hannan NJ, Gardner DK. Paternal obesity in a rodent model affects placental gene expression in a sex-specific manner. Reproduction. 2015;149:435-44. 
24. Owen DH, Katz DFA. Review of the physical and chemical properties of human semen and the formulation of a semen simulant. J Androl. 2005;26:459-69.

25. Buckett WM, Lewis-Jones DI. Fructose concentrations in seminal plasma from men with nonobstructive azoospermia. Arch Androl. 2002;48:23-7.

26. Konrad L, Schiemann P, Renneberg H, Wennemuth G, Fini C, Aumuller G. Expression and enzymic activity of ecto 5'-nucleotidase in the human male genital tract. Biol Reprod. 1998;59:190-6.

27. Peitz B, Olds-Clarke P. Effects of seminal vesicle removal on fertility and uterine sperm motility in the house mouse. Biol Reprod. 1986;35:608-17.

28. O'Mahony OA, Djahanbahkch O, Mahmood T, Puddefoot JR, Vinson GP. Angiotensin II in human seminal fluid. Hum Reprod. 2000;15:1345-9.

29. Katila T. Post-mating inflammatory responses of the uterus. Reprod Domest Anim. 2012;47(Suppl 5):31-41.

30. Bromfield JJ, Schjenken JE, Chin PY, Care AS, Jasper MJ, Robertson SA. Maternal tract factors contribute to paternal seminal fluid impact on metabolic phenotype in offspring. Proc Natl Acad Sci U S A. 2014;111:2200-5.

31. Lane M, McPherson NO, Fullston T, Spillane M, Sandeman L, Kang WX, et al. Oxidative stress in mouse sperm impairs embryo development, fetal growth and alters adiposity and glucose regulation in female offspring. PLoS One. 2014;9:e100832.

32. Lane M, Robker RL, Robertson SA. Parenting from before conception. Science. 2014;345:756-60.

33. Robertson SA. Seminal plasma and male factor signalling in the female reproductive tract. Cell Tissue Res. 2005;322:43-52.

34. Binder NK, Sheedy JR, Hannan NJ, Gardner DK. Male obesity is associated with changed spermatozoa Cox4i1 mRNA level and altered seminal vesicle fluid composition in a mouse model. Mol Hum Reprod. 2015;21:424-34.

35. Eisenberg ML, Kim S, Chen Z, Sundaram R, Schisterman EF, Buck Louis GM The relationship between male BMI and waist circumference on semen quality: data from the LIFE study. Hum Reprod. 2014;29:193-200.

36. Martini AC, Tissera A, Estofan D, Molina RI, Mangeaud A, de Cuneo MF, et al. Overweight and seminal quality: a study of 794 patients. Fertil Steril. 2010; 94:1739-43.

37. Lotti F, Corona G, Colpi GM, Filimberti E, Degli Innocenti S, Mancini M, et al. Elevated body mass index correlates with higher seminal plasma interleukin 8 levels and ultrasonographic abnormalities of the prostate in men attending an andrology clinic for infertility. J Endocrinol Investig. 2011;34:e336-42.

38. Thomas S, Kratzsch D, Schaab M, Scholz M, Grunewald S, Thiery J, et al. Seminal plasma adipokine levels are correlated with functional characteristics of spermatozoa. Fertil Steril. 2013;99:1256-63. e1253

39. Leisegang K, Bouic PJ, Menkveld R, Henkel RR. Obesity is associated with increased seminal insulin and leptin alongside reduced fertility parameters in a controlled male cohort. Reprod Biol Endocrinol. 2014;12:34.

40. Said L, Galeraud-Denis I, Carreau S, Saad A. Relationship between semen quality and seminal plasma components: alpha-glucosidase, fructose and citrate in infertile men compared with a normospermic population of Tunisian men. Andrologia. 2009;41:150-6.

41. Jayaraman V, Ghosh S, Sengupta A, Srivastava S, Sonawat HM, Narayan PK. Identification of biochemical differences between different forms of male infertility by nuclear magnetic resonance (NMR) spectroscopy. J Assist Reprod Genet. 2014;31:1195-204.

42. Richthoff J, Spano M, Giwercman YL, Frohm B, Jepson K, Malm J, et al. The impact of testicular and accessory sex gland function on sperm chromatin integrity as assessed by the sperm chromatin structure assay (SCSA). Hum Reprod. 2002;17:3162-9.

43. Raj V, Vijayan AN, Joseph K. Naked eye detection of infertility using fructose blue-a novel gold nanoparticle based fructose sensor. Biosens Bioelectron. 2014;54:171-4

44. Jope T, Lammert A, Kratzsch J, Paasch U, Glander HJ. Leptin and leptin receptor in human seminal plasma and in human spermatozoa. Int J Androl. 2003;26:335-41.

45. Tremellen KP, Seamark RF, Robertson SA. Seminal transforming growth factor beta1 stimulates granulocyte-macrophage colony-stimulating factor production and inflammatory cell recruitment in the murine uterus. Biol Reprod. 1998;58:1217-25.

46. Weinbauer GF, Luetjens CM, Simoni M, Nieschlag E. Physiology of Testicular Function. In: Nieschlag E., Behre H.M., Nieschlag S. (eds) Andrology. Springer, Berlin, Heidelberg; 2008:11-59.

47. Basaria S. Male hypogonadism. Lancet. 2014;383(9924):1250-63.

48. Huhtaniem il: Ontogeny of the luteinizing hormone action in the male. Cache River press; 1996.
49. Anderson DC. Sex-hormone-binding globulin. Clin Endocrinol. 1974;3:69-96.

50. Drago F, Lo Presti L, Nardo F, Panella I, Matera M, Scapagnini U. Aromatization of testosterone by adipose tissue and sexual behavior of castrated male rats. Biol Reprod. 1982;27:765-70.

51. Gautier A, Bonnet F, Dubois S, Massart C, Grosheny C, Bachelot A, et al. Associations between visceral adipose tissue, inflammation and sex steroid concentrations in men. Clin Endocrinol. 2013;78:373-8.

52. Hautanen A. Synthesis and regulation of sex hormone-binding globulin in obesity. Int J Obes Relat Metab Disord. 2000;24(Suppl 2):S64-70.

53. Michalakis K, Mintziori G, Kaprara A, Tarlatzis BC, Goulis DG. The complex interaction between obesity, metabolic syndrome and reproductive axis: a narrative review. Metabolism. 2013;62:457-78,

54. Amrolia P, Sullivan MH, Garside D, Baldwin SA, Cooke BA. An investigation of glucose uptake in relation to steroidogenesis in rat testis and tumour Leydig cells. Biochem J. 1988;249:925-8.

55. ZH L, YM M, Wang BA, Li XL, JM L, Li JY, et al. Saturated free fatty acids, palmitic acid and stearic acid, induce apoptosis by stimulation of ceramide generation in rat testicular Leydig cell. Biochem Biophys Res Commun. 2003;303:1002-7.

56. Rato L, Alves MG, Cavaco JE, Oliveira PF. High-energy diets: a threat for male fertility? Obes Rev. 2014;15:996-1007.

57. McPherson NO, Bell VG, Zander-Fox DL, Fullston T, LL W, Robker RL, et al. When two obese parents are worse than one! Impacts on embryo and fetal development. Am J Physiol Endocrinol Metab. 2015;309:E568-81.

58. Neto FT, Bach PV, Najari BB, Li PS, Goldstein M. Spermatogenesis in humans and its affecting factors. Semin Cell Dev Biol. 2016;59:10-26.

59. Oonk RB, Grootegoed JA, van der Molen HJ. Comparison of the effects of insulin and follitropin on glucose metabolism by Sertoli cells from immature rats. Mol Cell Endocrinol. 1985;42:39-48.

60. Boussouar F, Benahmed M. Lactate and energy metabolism in male germ cells. Trends Endocrinol Metab. 2004;15:345-50.

61. Erkkila K, Aito H, Aalto K, Pentikainen V, Dunkel L. Lactate inhibits germ cell apoptosis in the human testis. Mol Hum Reprod. 2002;8:109-17.

62. Alves MG, Oliveira PF, Socorro S, Moreira PI. Impact of diabetes in bloodtestis and blood-brain barriers: resemblances and differences. Curr Diabetes Rev. 2012;8:401-12.

63. Wathes DC, Abayasekara DR, Aitken RJ. Polyunsaturated fatty acids in male and female reproduction. Biol Reprod. 2007;77:190-201.

64. Dominguez-Vias G, Segarra AB, Martinez-Canamero M, Ramirez-Sanchez M, Prieto I. Influence of a virgin olive oil versus butter plus cholesterol-enriched diet on testicular enzymatic activities in adult male rats. Int J Mol Sci. 2017; 18(8). doi:10.3390/ijms18081701.

65. Fan Y, Liu Y, Xue K, Gu G, Fan W, Xu Y, et al. Diet-induced obesity in male C57BL/6 mice decreases fertility as a consequence of disrupted blood-testis barrier. PLoS One. 2015;10:e0120775.

66. Ehmcke J, Wistuba J, Schlatt S. Spermatogonial stem cells: questions, models and perspectives. Hum Reprod Update. 2006;12:275-82

67. Huang G, Yuan M, Zhang J, Li J, Gong D, Li Y, Zhang J, Lin P, Huang L. IL-6 mediates differentiation disorder during spermatogenesis in obesity-associated inflammation by affecting the expression of Zfp637 through the SOCS3/STAT3 pathway. Sci Rep. 2016;6:28012.

68. Ivell R. Lifestyle impact and the biology of the human scrotum. Reprod Biol Endocrinol. 2007;5:15.

69. Durairajanayagam D, Agarwal A, Ong C. Causes, effects and molecular mechanisms of testicular heat stress. Reprod BioMed Online. 2015;30:14-27.

70. Nguyen RH, Wilcox AJ, Skjaerven R, Baird DD. Men's body mass index and infertility. Hum Reprod. 2007;22:2488-93.

71. Ramlau-Hansen $\mathrm{CH}$, Thulstrup AM, Bonde JP, Olsen J. Parental infertility and semen quality in male offspring: a follow-up study. Am J Epidemiol. 2007; 166:568-70.

72. Sallmen M, Sandler DP, Hoppin JA, Blair A, Baird DD. Reduced fertility among overweight and obese men. Epidemiology. 2006;17:520-3.

73. Sermondade N, Faure C, Fezeu L, Shayeb AG, Bonde JP, Jensen TK, et al. BMI in relation to sperm count: an updated systematic review and collaborative meta-analysis. Hum Reprod Update. 2013;19:221-31.

74. Hammoud AO, Wilde N, Gibson M, Parks A, Carrell DT, Meikle AW. Male obesity and alteration in sperm parameters. Fertil Steril. 2008;90: 2222-5.

75. Kort HI, Massey JB, Elsner CW, Mitchell-Leef D, Shapiro DB, Witt MA, et al. Impact of body mass index values on sperm quantity and quality. J Androl. 2006;27:450-2. 
76. Chavarro JE, Toth TL, Wright DL, Meeker JD, Hauser R. Body mass index in relation to semen quality, sperm DNA integrity, and serum reproductive hormone levels among men attending an infertility clinic. Fertil Steril. 2010; 93:2222-31.

77. Kodama H, Yamaguchi R, Fukuda J, Kasai H, Tanaka T. Increased oxidative deoxyribonucleic acid damage in the spermatozoa of infertile male patients. Fertil Steril. 1997;68:519-24.

78. Sikka SC. Relative impact of oxidative stress on male reproductive function. Curr Med Chem. 2001;8:851-62.

79. Rato L, Duarte Al, Tomas GD, Santos MS, Moreira PI, Socorro S, et al. Prediabetes alters testicular PGC1-alpha/SIRT3 axis modulating mitochondrial bioenergetics and oxidative stress. Biochim Biophys Acta. 2014;1837:335-44.

80. Tunc O, Bakos HW, Tremellen K. Impact of body mass index on seminal oxidative stress. Andrologia. 2011;43:121-8.

81. Palmer NO, Fullston T, Mitchell M, Setchell BP, Lane M. SIRT6 in mouse spermatogenesis is modulated by diet-induced obesity. Reprod Fertil Dev. 2011;23:929-39.

82. Duale N, Steffensen IL, Andersen J, Brevik A, Brunborg G, Lindeman B. Impaired sperm chromatin integrity in obese mice. Andrology. 2014;2:234-43.

83. Vendramini V, Cedenho AP, Miraglia SM, Spaine DM. Reproductive function of the male obese Zucker rats: alteration in sperm production and sperm DNA damage. Reprod Sci (thousand oaks, Calif). 2014;21:221-9.

84. Bakos HW, Mitchell M, Setchell BP, Lane M. The effect of paternal diet-induced obesity on sperm function and fertilization in a mouse model. Int J Androl. 2011;34:402-10.

85. Chen XL, Gong LZ, JX X. Antioxidative activity and protective effect of probiotics against high-fat diet-induced sperm damage in rats. Animal. 2013;7:287-92.

86. Zhao J, Zhai L, Liu Z, Wu S, Xu L. Leptin level and oxidative stress contribute to obesity-induced low testosterone in murine testicular tissue. Oxidative Med Cell Longev. 2014;2014:190945

87. Binder NK, Hannan NJ, Gardner DK. Paternal diet-induced obesity retards early mouse embryo development, mitochondrial activity and pregnancy health. PLoS One. 2012;7:e52304.

88. Mitchell M, Bakos HW, Lane M. Paternal diet-induced obesity impairs embryo development and implantation in the mouse. Fertil Steril. 2011;95:1349-53.

89. Colaci DS, Afeiche M, Gaskins AJ, Wright DL, Toth TL, Tanrikut C, et al. Men's body mass index in relation to embryo quality and clinical outcomes in couples undergoing in vitro fertilization. Fertil Steril. 2012;98:1193-9. e1191

90. Schliep KC, Mumford SL, Ahrens KA, Hotaling JM, Carrell DT, Link M, et al. Effect of male and female body mass index on pregnancy and live birth success after in vitro fertilization. Fertil Steril. 2015;103:388-95.

91. Sorahan T. Prior P, Lancashire RJ, faux SP, Hulten MA, peck IM, et al. childhood cancer and parental use of tobacco: deaths from 1971 to 1976. Br J Cancer. 1997:76:1525-31.

92. Chang JS, Selvin S, Metayer C, Crouse V, Golembesky A, Buffler PA. Parental smoking and the risk of childhood leukemia. Am J Epidemiol. 2006;163:1091-100.

93. Toschke AM, Ehlin A, Koletzko B, Montgomery SM. Paternal smoking is associated with a decreased prevalence of type 1 diabetes mellitus among offspring in two national British birth cohort studies (NCDS and BCS70). J Perinat Med. 2007;35:43-7.

94. Fernandez-Gonzalez R, Moreira PN, Perez-Crespo M, Sanchez-Martin M, Ramirez MA, Pericuesta $\mathrm{E}$, et al. Long-term effects of mouse intracytoplasmic sperm injection with DNA-fragmented sperm on health and behavior of adult offspring. Biol Reprod. 2008;78:761-72.

95. Lin CC, Wang JD, Hsieh GY, Chang YY, Chen PC. Increased risk of death with congenital anomalies in the offspring of male semiconductor workers. Int J Occup Environ Health. 2008;14:112-6.

96. Sung TI, Wang JD, Chen PC. Increased risks of infant mortality and of deaths due to congenital malformation in the offspring of male electronics workers. Birth Defects Res A Clin Mol Teratol. 2009:85:119-24

97. Sartorius GA, Nieschlag E. Paternal age and reproduction. Hum Reprod Update 2010;16:65-79.

98. Byers SA, Price JP, Cooper JJ, Li Q, Price DH. HEXIM2, a HEXIM1-related protein, regulates positive transcription elongation factor $b$ through association with 7SK. J Biol Chem. 2005;280:16360-7.

99. Bygren LO, Kaati G, Edvinsson S. Longevity determined by paternal ancestors' nutrition during their slow growth period. Acta Biotheor. 2001;49:53-9.

100. Kaati G, Bygren LO, Edvinsson S. Cardiovascular and diabetes mortality determined by nutrition during parents' and grandparents' slow growth period. Eur J Hum Genet. 2002;10:682-8.
101. Kaati G, Bygren LO, Pembrey M, Sjostrom M. Transgenerational response to nutrition, early life circumstances and longevity. Eur J Hum Genet. 2007;15:784-90.

102. Pembrey ME, Bygren LO, Kaati G, Edvinsson S, Northstone K, Sjostrom M, et al. Sex-specific, male-line transgenerational responses in humans. Eur J Hum Genet. 2006;14:159-66

103. Chen Q, Yan M, Cao Z, Li X, Zhang Y, Shi J, et al. Sperm tsRNAs contribute to intergenerational inheritance of an acquired metabolic disorder. Science. 2016;351:397-400.

104. de Castro Barbosa T, Ingerslev LR, Alm PS, Versteyhe S, Massart J, Rasmussen M, et al. High-fat diet reprograms the epigenome of rat spermatozoa and transgenerationally affects metabolism of the offspring. Mol Metab. 2016;5:184-97.

105. Fullston T, Ohlsson Teague EM, Palmer NO, DeBlasio MJ, Mitchell M, et al. Paternal obesity initiates metabolic disturbances in two generations of mice with incomplete penetrance to the F2 generation and alters the transcriptional profile of testis and sperm microRNA content. FASEB. 2013;27:4226-43.

106. Sharma U, Conine CC, Shea JM, Boskovic A, Derr AG, Bing XY, et al. Biogenesis and function of tRNA fragments during sperm maturation and fertilization in mammals. Science. 2016;351:391-6.

107. Ng SF, Lin RC, Laybutt DR, Barres R, Owens JA, Morris MJ. Chronic high-fat diet in fathers programs beta-cell dysfunction in female rat offspring. Nature. 2010;467:963-6.

108. An T, Zhang T, Teng F, Zuo JC, Pan YY, Liu YF, et al. Long non-coding RNAs could act as vectors for paternal heredity of high fat diet-induced obesity. Oncotarget. 2017:8:47876-89

109. Cropley JE, Eaton SA, Aiken A, Young PE, Giannoulatou E, Ho JW, et al. Malelineage transmission of an acquired metabolic phenotype induced by grand-paternal obesity. Mol metab. 2016:5:699-708.

110. Hanafi MY, Saleh MM, Saad MI, Abdelkhalek TM, Kamel MA. Transgenerational effects of obesity and malnourishment on diabetes risk in F2 generation. Mol Cell Biochem. 2016;412:269-80.

111. Jimenez-Chillaron JC, Isganaitis E, Charalambous M, Gesta S, Pentinat-Pelegrin $T$, Faucette RR, et al. Intergenerational transmission of glucose intolerance and obesity by in utero undernutrition in mice. Diabetes. 2009;58:460-8.

112. Murashov AK, Pak ES, Koury M, Ajmera A, Jeyakumar M, Parker M, et al. Paternal long-term exercise programs offspring for low energy expenditure and increased risk for obesity in mice. FASEB J. 2016;30:775-84.

113. Terashima M, Barbour S, Ren J, Yu W, Han Y, Muegge K. Effect of high fat diet on paternal sperm histone distribution and male offspring liver gene expression. Epigenetics. 2015;10:861-71.

114. Wang Y, Liu H, Sun Z. Lamarck rises from his grave: parental environmentinduced epigenetic inheritance in model organisms and humans. Biol Rev Camb Philos Soc. 2017;92(4):2084-111.

115. Hotchkiss RD. The quantitative separation of purines, pyrimidines, and nucleosides by paper chromatography. J Biol Chem. 1948;175:315-32.

116. Bird AP. CpG-rich islands and the function of DNA methylation. Nature. 1986;321:209-13.

117. Messerschmidt DM, Knowles BB, Solter DDNA. Methylation dynamics during epigenetic reprogramming in the germline and preimplantation embryos. Genes Dev. 2014;28:812-28.

118. Barlow DP, Bartolomei MS. Genomic imprinting in mammals. Cold Spring Harb Perspect Biol. 2014;6(2). doi:10.1101/cshperspect.a01832.

119. Soubry A. Epigenetic inheritance and evolution: a paternal perspective on dietary influences. Prog Biophys Mol Biol. 2015;118:79-85.

120. Soubry A, Guo L, Huang Z, Hoyo C, Romanus S, Price T, et al. Obesityrelated DNA methylation at imprinted genes in human sperm: results from the TIEGER study. Clin Epigen. 2016;8:51.

121. Baker MS, Li G, Kohorst JJ, Waterland RA. Fetal growth restriction promotes physical inactivity and obesity in female mice. Int J Obes. 2015;39:98-104.

122. Kohl HW 3rd, Craig CL, Lambert EV, Inoue S, Alkandari JR, Leetongin G, Kahlmeier S. The pandemic of physical inactivity: global action for public health. Lancet. 2012;380:294-305.

123. Shea JM, Serra RW, Carone BR, Shulha HP, Kucukural A, Ziller MJ, et al. Genetic and epigenetic variation, but not diet, shape the sperm Methylome. Dev Cell. 2015;35:750-8.

124. Hecht NB. Mammalian protamines and their expression. In: I I, Stein G, Stein J, editors. Histones and other basic nuclear proteins. Orlando: CRC press; 1989. p. 347-73.

125. Banerjee S, Smallwood A, Hulten M. ATP-dependent reorganization of human sperm nuclear chromatin. J Cell Sci. 1995;108(Pt 2):755-65.

126. Ward WS. Function of sperm chromatin structural elements in fertilization and development. Mol Hum Reprod. 2010;16:30-6. 
127. Hammadeh ME, Hamad MF, Montenarh M, Fischer-Hammadeh C. Protamine contents and P1/P2 ratio in human spermatozoa from smokers and nonsmokers. Hum Reprod. 2010;25:2708-20.

128. Iuchi Y, Kaneko T, Matsuki S, Sasagawa I, Fujii J. Concerted changes in the YB2/RYB-a protein and protamine 2 messenger RNA in the mouse testis under heat stress. Biol Reprod. 2003;68:129-35.

129. Love CC, Kenney RM. Scrotal heat stress induces altered sperm chromatin structure associated with a decrease in protamine disulfide bonding in the stallion. Biol Reprod. 1999;60:615-20.

130. Ni K, Spiess AN, Schuppe HC, Steger K. The impact of sperm protamine deficiency and sperm DNA damage on human male fertility: a systematic review and meta-analysis. Andrology. 2016;4:789-99.

131. Hammoud SS, Nix DA, Hammoud AO, Gibson M, Cairns BR, Carrell DT. Genome-wide analysis identifies changes in histone retention and epigenetic modifications at developmental and imprinted gene loci in the sperm of infertile men. Hum Reprod. 2011;26:2558-69.

132. Hammoud SS, Nix DA, Zhang H, Purwar J, Carrell DT, Cairns BR. Distinctive chromatin in human sperm packages genes for embryo development. Nature. 2009:460:473-8.

133. Hammoud SS, Low DH, Yi C, Carrell DT, Guccione E, Cairns BR. Chromatin and transcription transitions of mammalian adult germline stem cells and spermatogenesis. Cell Stem Cell. 2014;15:239-53.

134. Jenkins TG, Carrell DT. The sperm epigenome and potential implications for the developing embryo. Reproduction. 2012;143:727-34.

135. Amiri I, Karimi J, Piri H, Goodarzi MT, Tavilani H, Khodadadi I, et al. Association between nitric oxide and 8-hydroxydeoxyguanosine levels in semen of diabetic men. Syst Biol Reprod Med. 2011;57:292-5.

136. Carone BR, Fauquier L, Habib N, Shea JM, Hart CE, Li R, et al. Paternally induced transgenerational environmental reprogramming of metabolic gene expression in mammals. Cell. 2010;143:1084-96.

137. Schuster A, Tang C, Xie Y, Ortogero N, Yuan S, Yan W. SpermBase: a database for sperm-borne RNA contents. Biol Reprod. 2016;95(5):99.

138. Liu WM, Pang RT, Chiu PC, Wong BP, Lao K, Lee KF, et al. Sperm-borne microRNA-34C is required for the first cleavage division in mouse. Proc Natl Acad Sci U S A. 2012:109:490-4.

139. Yuan S, Schuster A, Tang C, Yu T, Ortogero N, Bao J, et al. Sperm-borne miRNAs and endo-siRNAs are important for fertilization and preimplantation embryonic development. Development. 2016;143:635-47.

140. Grandjean V, Gounon P, Wagner N, Martin L, Wagner KD, Bernex F, et al. The miR-124-Sox9 paramutation: RNA-mediated epigenetic control of embryonic and adult growth. Development. 2009;136:3647-55.

141. Rassoulzadegan M, Grandjean V, Gounon P, Vincent S, Gillot I, Cuzin F. RNAmediated non-mendelian inheritance of an epigenetic change in the mouse. Nature. 2006:441:469-74.

142. Wagner KD, Wagner N, Ghanbarian H, Grandjean V, Gounon P, Cuzin F, et al. RNA induction and inheritance of epigenetic cardiac hypertrophy in the mouse. Dev Cell. 2008;14:962-9.

143. Gapp K, Jawaid A, Sarkies P, Bohacek J, Pelczar P, Prados J, et al. Implication of sperm RNAs in transgenerational inheritance of the effects of early trauma in mice. Nat Neurosci. 2014;17:667-9.

144. Okada Y, Yamaguchi K. Epigenetic modifications and reprogramming in paternal pronucleus: sperm, preimplantation embryo, and beyond. Cell Mol Life Sci. 2017;74:1957-67.

145. Short AK, Yeshurun S, Powell R, Perreau VM, Fox A, Kim JH, et al. Exercise alters mouse sperm small noncoding RNAs and induces a transgenerational modification of male offspring conditioned fear and anxiety. Transl Psychiatry. 2017;7:e1114.

146. Gapp K, Bohacek J, Grossmann J, Brunner AM, Manuella F, Nanni P, et al. Potential of environmental enrichment to prevent transgenerational effects of paternal trauma. Neuropsychopharmacology. 2016;41:2749-58.

147. De Lorenzo A, Soldati L, Sarlo F, Calvani M, Di Lorenzo N, Di Renzo L. New obesity classification criteria as a tool for bariatric surgery indication. World J Gastroenterol. 2016;22:681-703.

\section{Submit your next manuscript to BioMed Central and we will help you at every step:}

- We accept pre-submission inquiries

- Our selector tool helps you to find the most relevant journal

- We provide round the clock customer support

- Convenient online submission

- Thorough peer review

- Inclusion in PubMed and all major indexing services

- Maximum visibility for your research

Submit your manuscript at www.biomedcentral.com/submit
Biomed Central 